\title{
논문 6
}

[2013-03-OE-006]

\section{영구자석 동기발전기와 회류수조를 \\ 이용한 조류발전 시스템의 특성 해석}

안원영*, 이석현**, 김근수, 이강희, 조철희

\section{Analysis of the Characteristics of the Tidal Current Power Generation System Using PMSG and Water Tunnel}

Won-Young An*, Seok-Hyun Lee**, Gun-Su Kim, Kang-Hee Lee and Chul-Hee Jo

Abstract In order to analyze the characteristics of tidal current power generation system, we measured the output power according to the stream velocity by a water tunnel system and a simulation in MATLAB/Simulink. The water tunnel system consisted of impeller tidal flow transducer and PMSG with rotor in the water. The simulation consisted of PMSG, the tidal current turbine, and back-to-back converter. Also, we simulated the characteristics of output power according to the change of blade length and angular velocity.

Key words MATLAB/Simulink, Tidal flow power generation(조류 발전), water tunnel(회류 수조), PMSG(영구자석형 동기발전기)

(접수일 2013. 1. 10, 수정일 2013. 3. 12, 게재확정일 2013. 3. 14)

* 인하대학교 해양에너지환경 융합기술연구소 (Department of Electrical Engineering, Inha University)

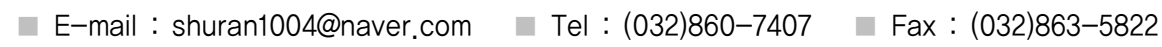

** 교신저자, 인하대학교 전기공학부 (Department of Electrical Engineering, Inha University)

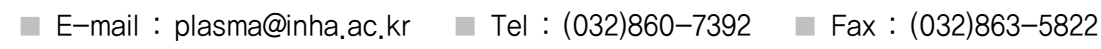

\section{Nomenclature}

$C_{p}:$ power coefficient

$\lambda: T S R$

$V$ : stream velocity, $\mathrm{m} / \mathrm{s}$

\section{Subscript}

PMSG : Permanent Magnet Synchronous Generator TSR : Tip Speed Ratio

\section{1. 서 론}

화석에너지의 고갈과 환경오염에 대한 관심이 커짐에 따라 인류의 문명과 기술의 발전에 크게 영향을 미친 화석에너지 원은 우리의 일상생활에 매우 위험한 요소로 다가오고 있다. 아울러 전 세계적으로 인구증가는 더욱 많은 전기에너지를 필요로 할 것이다. 그리고 화석에너지의 더 많은 이용에 따른 매장량 감소는 미래의 발전에 장해가 될 것이다. 이에 따라 앞으로 에너지 문제를 해결하기 위해서는 화석에너지를 보다 
효과적으로 이용함과 동시에 원자력 에너지의 안전한 이용을 포함하여 신재생에너지원의 이용을 높이는 기술 개발이 필요 하다. 더구나 전력산업의 구조개편이 세계적인 추세로 자리 함으로써 신재생에너지의 입지변화는 필연적으로 여겨진다 ${ }^{(1)}$. 조류발전은 해수의 유동으로 터빈이나 로터를 구동시켜서 이 때 발생하는 운동에너지를 전기에너지로 변환하여 에너지 를 생산하는 기술로서 유속이 빠른 지역에 적용하게 된다. 일 반적으로 조류발전을 위한 해수의 유속은 최소 $1 \mathrm{~m} / \mathrm{s}$ 이다. 그 러나 경제성 등을 고려할 때에는 $2 \mathrm{~m} / \mathrm{s}$ 이상인 곳에 설치하게 된다. 이에 따라 조류발전은 기존의 에너지원과 비교해도 차 이가 없고 발전비용이 저렴해서 청정에너지원으로 손색이 없 음을 확인할 수 있다. 또한 조류발전은 발전량을 예측하기 힘 든 태양광이나 풍력발전에 비해 발전량을 예측할 수 있는 장 점을 가지고 있다 ${ }^{(2)}$.

본 논문에서는 조류발전 시스템의 성능 및 특성을 효율적 으로 시험하기 위해서 모의실험 장치인 회류수조를 구성하였 고, 이를 검증하기 위하여 MATLAB/Simulink를 이용하여 시뮬레이션을 수행하였다. 본 실험에서는 영구자석 동기발전 기에 Back-to-Back 컨버터를 사용하였다. 또한 블레이드의 길이와 각속도를 변화시켰을 때 출력변화를 확인했다.

\section{2. 본 론}

\section{1 조류발전 시스템}

조류발전기 시스템에서 블레이드는 유체의 유동에너지를 회전에너지로 변환하여 발전기에 공급하는 부분이다. 블레이 드의 기계적 에너지인 $P_{b l a d e}$ 는 식 (1)과 같이 나타낼 수 있다 ${ }^{(3)}$.

$$
P_{\text {blade }}=\frac{1}{2} A \rho V_{\text {water }}^{3} C_{p}(\lambda)[W]
$$

여기서, $P_{\text {blade }}$ 는 조류터빈에 포획되는 전력[W], A는 회전 단면적[ $\left[\mathrm{m}^{2}\right], \rho$ 는 유체의 밀도, $V_{\text {water }}$ 는 유속[m/s], $\lambda$ 는 주속 비, $C_{p}$ 는 출력계수이다. 매 순간마다 유속의 변화에 따라 현 재 회전 속도에서 블레이드가 입력할 수 있는 토크 $T_{\text {blade }}$ 는 식 (2)와 같이 계산할 수 있다.

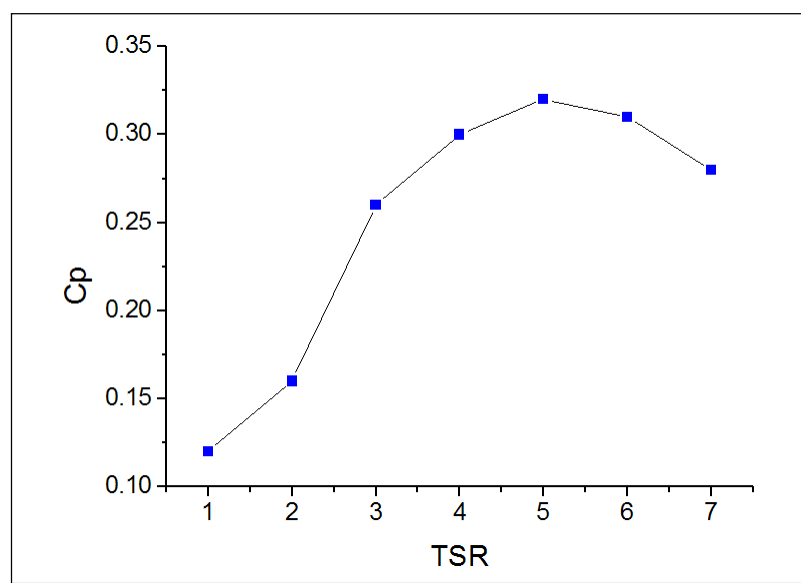

Fig. $1 \mathrm{Cp}$ and TSR Characteristic of Tidal Power System

$$
T_{\text {blade }}=\frac{P_{\text {blade }}}{w_{\text {blade }}}=\frac{1}{2} A \rho V_{\text {water }}^{3} \frac{C_{p}}{w_{\text {blade }}}[\mathrm{N} \cdot \mathrm{m}]
$$

이 때 출력계수의 계산에 주의하여야 한다. 출력계수란 유 속이 가지고 있는 전체 에너지 중에서 블레이드가 받아들이 는 에너지의 비율을 의미하며, 유속에 대한 블레이드의 회전 속도 비율인 주속비(TSR) $\lambda$ 에 따라 변한다. 블레이드의 출력 계수는 식 (3)과 같이 근사화 하였다 ${ }^{(4)}$

$$
C_{p}(\lambda)=a_{3} \lambda^{3}+a_{2} \lambda^{2}+a_{1} \lambda+a_{0}
$$

여기서, $a_{0}=-0.0058634, a_{1}=0.1473530$, $a_{2}=-0.019876, a_{3}=0.0006518$ 이다. 또한 주속비 $\lambda$ 는 다음과 같이 정의된다.

$$
\lambda=\frac{w_{\text {blade }} R_{\text {blade }}}{V_{\text {water }}}
$$

터빈 블레이드의 회전면적과 유속 밀도가 일정하다면, 전 력변환 계수 $\left(C_{p}\right)$ 는 Fig. 1 과 같이 주속비 $\lambda$ 가 $\lambda_{o p t}$ 값으로 갖 는 속도를 가질 때 최대값이 된다.

\section{2 영구자석 동기기 모델링}

영구자석 동기기는 회전자에 자속발생을 위한 여자 권선 이 없으므로 이로 인한 손실이 없어 효율이 좋으며, 고출력 
밀도를 가지고 있어 전동기 무게에 대한 출력 토크의 비가 크 고 속응성이 좋은 장점을 가지고 있다.

\subsection{1 고정자 전압방정식}

영구자석 동기기의 $d-q$ 축 등가회로는 Fig. 2 와 같이 나타 낼 수 있다.

영구자석 동기기의 고정자 전압방정식은 식 (5)와 같이 나 타낼 수 있다 ${ }^{(5)}$.

$$
\begin{aligned}
& V_{d s}=R_{s} i_{d s}+\frac{d}{d t} \lambda_{d s}-w \lambda_{q s} \\
& V_{q s}=R_{s} i_{q s}+\frac{d}{d t} \lambda_{q s}+w \lambda_{d s}
\end{aligned}
$$

\subsection{2 토크방정식}

영구자석 동기기의 토크는 전동기의 기계적 출력으로부터 구할 수 있다. $d-q$ 축 좌표계에서 전동기의 입력전압은 식 (6) 과 같이 표현된다.

$$
P_{I N}=\frac{3}{2}\left(v_{d} i_{d}+v_{q} i_{q}\right)
$$

토크는 이 기계적 출력을 전동기의 속도 $w$ 로 나눈 것이므 로 이로부터 $d-q$ 축 변수로 표현된 토크는 식 (7)과 같이 나타 낼 수 있다.

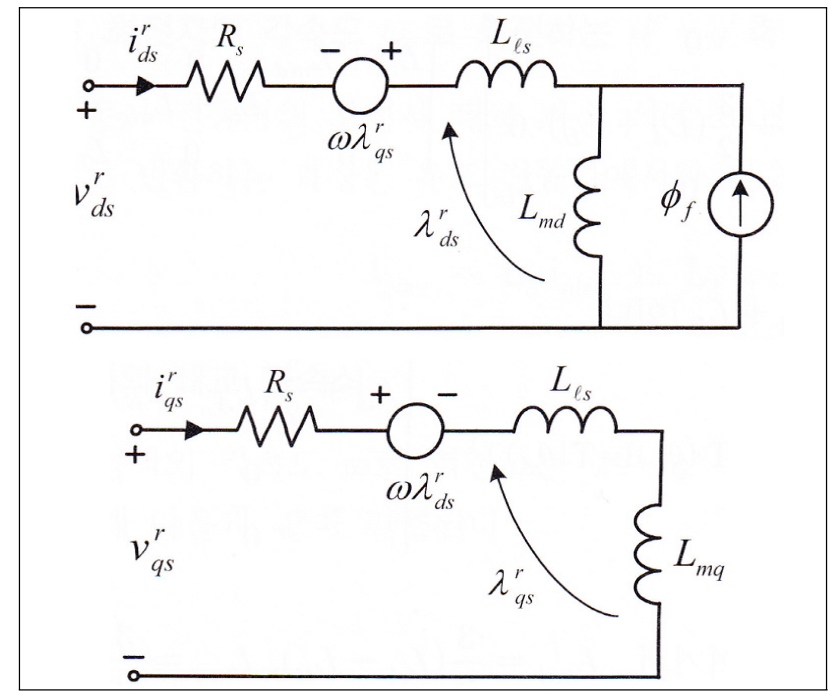

Fig. $2 \mathrm{~d}-\mathrm{q}$ Equivalent Circuit of PMSM

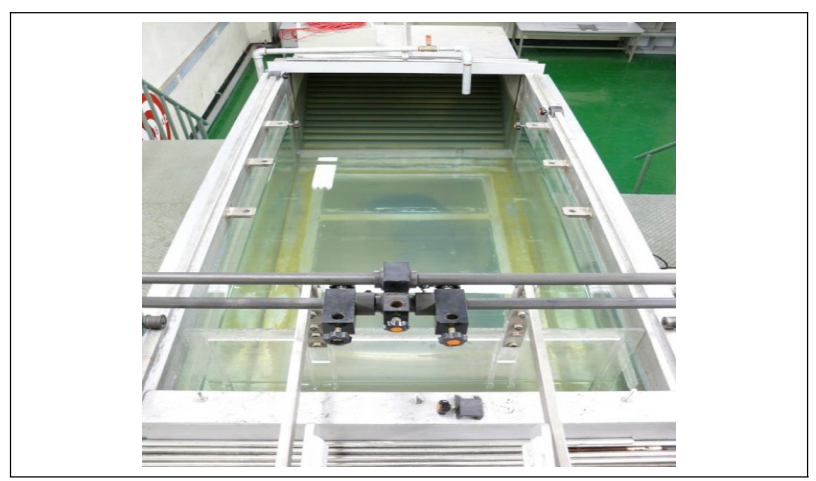

Fig. 3 Water Tunnel Simulator

$$
T_{e}=\frac{P}{2} \frac{3}{2}\left[\Phi_{f} i_{q s}+\left(L_{d s}-L_{q s}\right) i_{d s} i_{q s}\right]
$$

\section{3 회류수조}

조류발전 시스템을 모의실험하기 위해 구성한 회류수조를 Fig. 3에 나타내었다.

설치된 회류수조의 로터 직경은 $50 \mathrm{~cm}$ 로 제작하였고 최대 유속은 $1.2 \mathrm{~m} / \mathrm{s}$ 이다. 또한 로터의 회전축이 발전기와 일렬로 배치되는 소형 수중발전기 모델을 제작하여 회류수조에 설치 했다. 수중 발전형태의 발전기는 동력전달경로가 짧아 에너 지 손실 면에서 유리하다는 장점이 있지만, 수밀기술이 뒷받 침 되지 않으면 수면밖에 발전기가 위치하는 형태보다 더 큰 저항토크를 유발할 수 있다.

Table 1은 회류수조의 유속별 데이터를 나타낸 것이다. 로 터는 유속 $0.9 \mathrm{~m} / \mathrm{s} \sim 1.0 \mathrm{~m} / \mathrm{s}$ 사이에서 회전하기 시작했으며 회전 이후로는 관성력에 의해 $0.5 \mathrm{~m} / \mathrm{s}$ 유속까지 회전이 가능 했다. 실험 결과 유속이 $1 \mathrm{~m} / \mathrm{s}$ 이하일 때는 전력이 조금씩 증가 하다가 $1 \mathrm{~m} / \mathrm{s}$ 이상으로 커지면서 전력도 증가되는 것을 확인할 수 있다.

\section{Table 1. Output Power v.s. Stream Velocity}

\begin{tabular}{c|c|c|c}
\hline 유속 $(\mathrm{m} / \mathrm{s})$ & 전압 $(\mathrm{V})$ & 전류$(\mathrm{A})$ & 전력 $(\mathrm{W})$ \\
\hline 0.7 & 13 & 0.24 & 3.4 \\
\hline 0.8 & 17.5 & 0.34 & 5.1 \\
\hline 0.9 & 21.0 & 0.40 & 7.2 \\
\hline 1.0 & 23.8 & 0.48 & 10.8 \\
\hline 1.1 & 25.0 & 0.51 & 12.8 \\
\hline 1.2 & 26.0 & 0.70 & 17.4 \\
\hline
\end{tabular}




\section{3. 시뮬레이션}

조류발전 모의실험 장치인 회류수조의 실험결과를 검증하 기 위해서 MATLAB/Simulink를 사용하여 시뮬레이션을 수 행하였다. 조류 발전시스템은 크게 블레이드, 영구자석 동기 발전기, 컨버터, 인버터로 구성된다. 이를 바탕으로 조류발 전 시스템의 전체 시스템의 모델링한 것을 Fig. 4 에 나타내었다.

블레이드의 특성을 모델링하기 위하여 Fig. 5 와 같이 모델 링을 하였다. 식 (4)를 이용하여 TSR값을 구할 수 있도록 모 델링하였고 식 (3)을 사용해서 $\mathrm{Cp}$ 값을 계산할 수 있도록
Simulink Block Subsystem을 통해 모델링하였다. 이를 통 해 $P_{\text {blade }}$ 값을 계산하기 위해서 식 (1)을 이용하여 모델링하였 고 식 (2)를 통해 $T_{m}$ 값이 출력될 수 있도록 모델링을 하였다.

Fig. 6은 인버터 제어기를 모델링 한 것을 나타내었다. 컨 버터를 통해 $\mathrm{DC}$ 로 변환된 전압을 전압 지령치와 비슷한 값을 가질 수 있도록 PI제어기를 통해 DC전압과 지령치 값의 오차 를 줄이게 된다. 또한 전류를 제어하기 위해 좌표변환을 통해 $d-q$ 축 전류로 바꾼다. 여기서 $d$ 축 전류를 제어하여 PWM 신 호를 만든다.

Fig. 7은 회류수조의 실험과 시뮬레이션 값을 비교한 것이

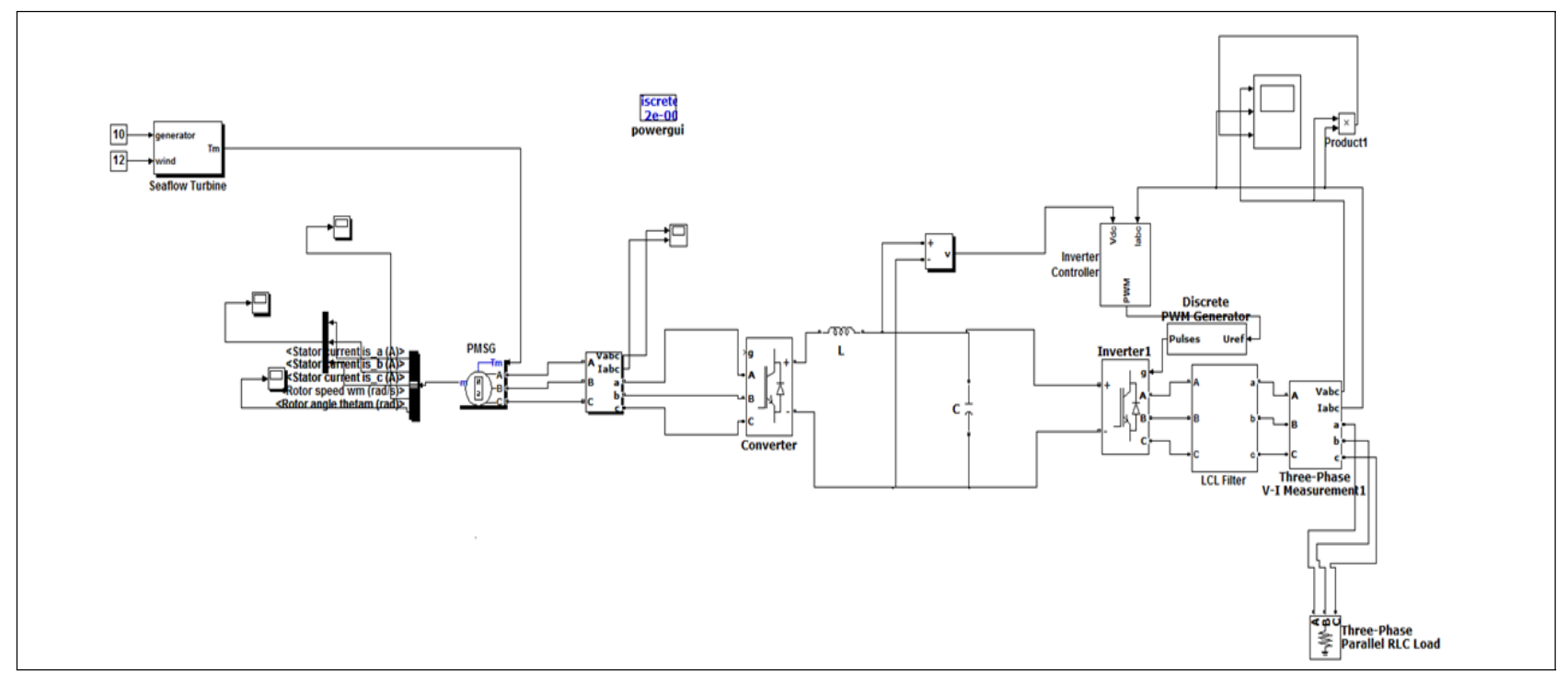

Fig. 4 Tidal Flow Power Generation Total modeling

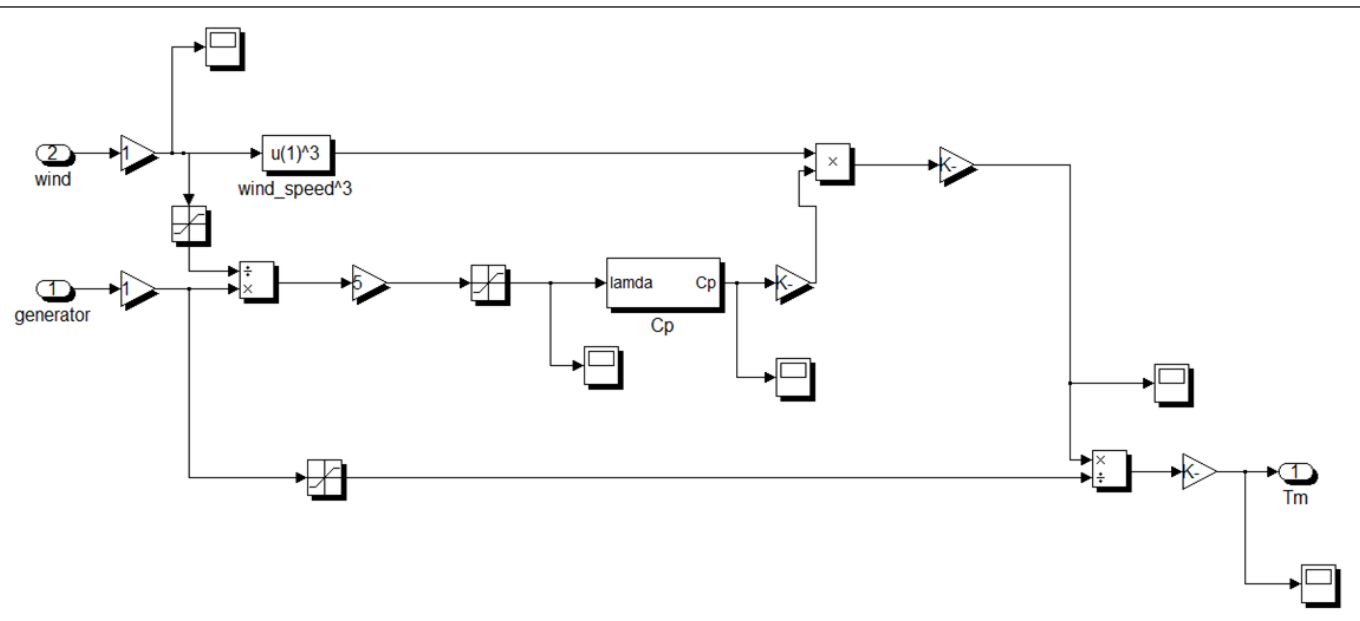

Fig. 5 Tidal Flow Turbine Model 


\section{논문 6}

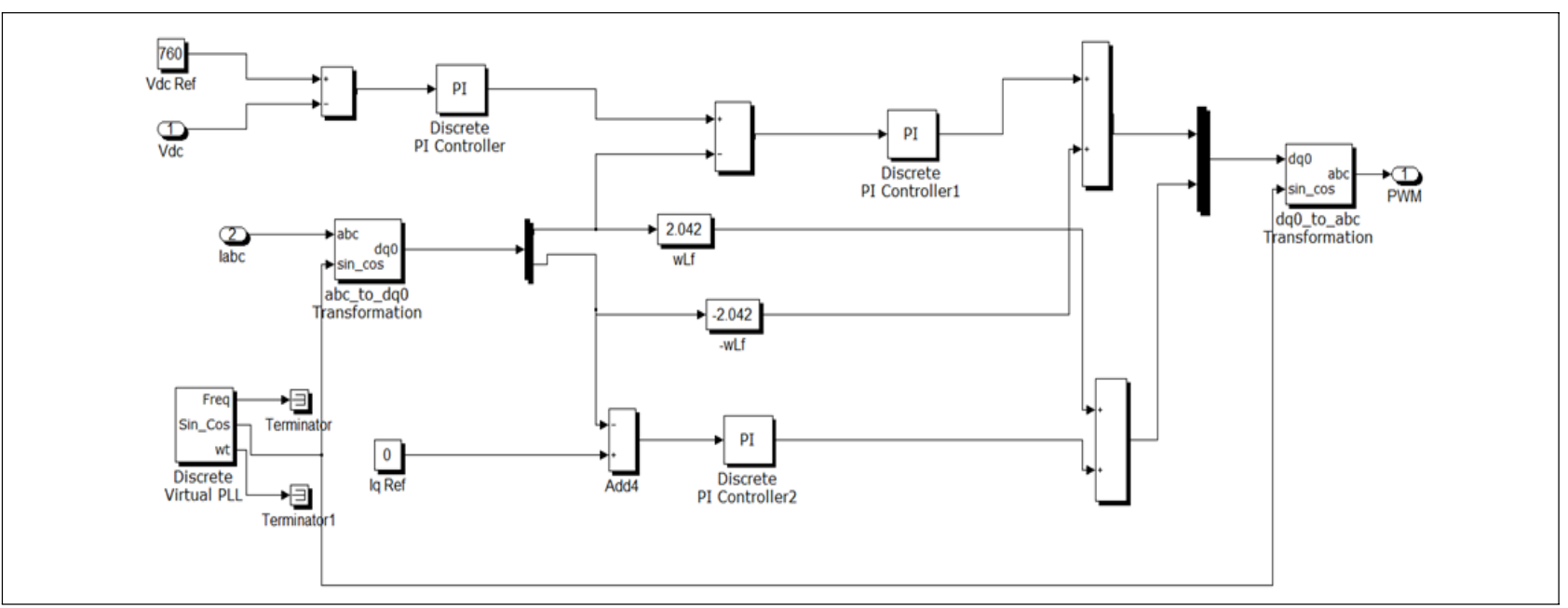

Fig. 6 Inverter Controller

다. 실제 실험한 값과 오차가 발생하였지만 비슷한 출력 값을 가지는 것을 확인할 수 있다. 식 (1)을 통해 $\mathrm{P}$ 값은 $V^{3}$ 에 비 례하는 것을 알 수 있다. 그러므로 유속이 증가하게 되면 블 레이드에 포획되는 전력도 증가하게 되는 것을 알 수 있다.

회류수조의 기본 데이터를 바탕으로 유속을 증가시킴에 따 라 출력의 변화를 알아보기 위해 시뮬레이션을 수행한 결과 값은 Fig. 8과 같이 나타난다. $\mathrm{P}$ 는 $V^{3}$ 에 비례하므로 Fig. 8은 Fig. 7과 같이 유속이 커질수록 $\mathrm{P}$ 값도 커지게 된다.

유속을 $2 \mathrm{~m} / \mathrm{s}$ 로 고정하고 블레이드의 반지름을 증가시켜 시뮬레이션을 수행한 결과 값은 Fig. 9와 같이 나타난다. 식 (4)를 통해 $\lambda$ 는 R에 비례한다. 따라서 $\mathrm{R}$ 값이 커지면 $\lambda$ 값도

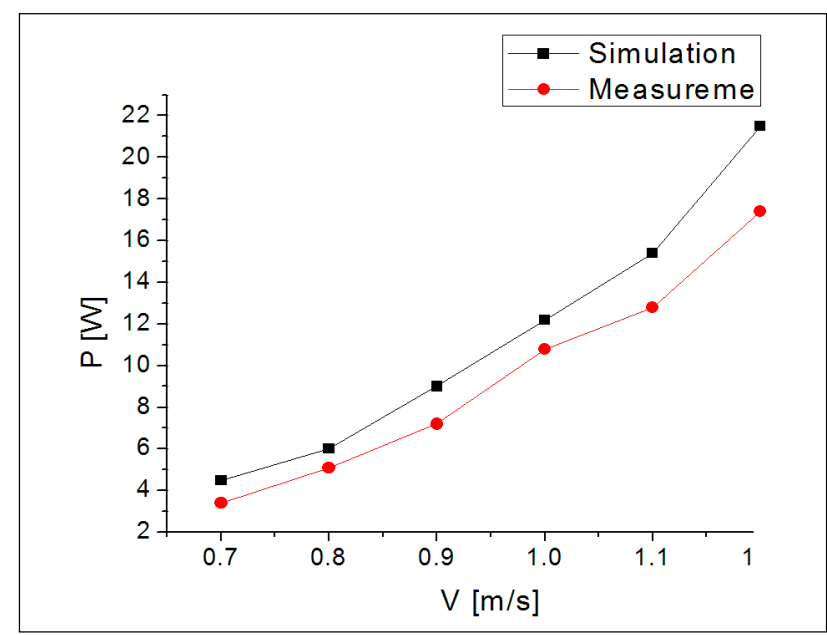

Fig. 7 Output Power v.s. Stream Velocity

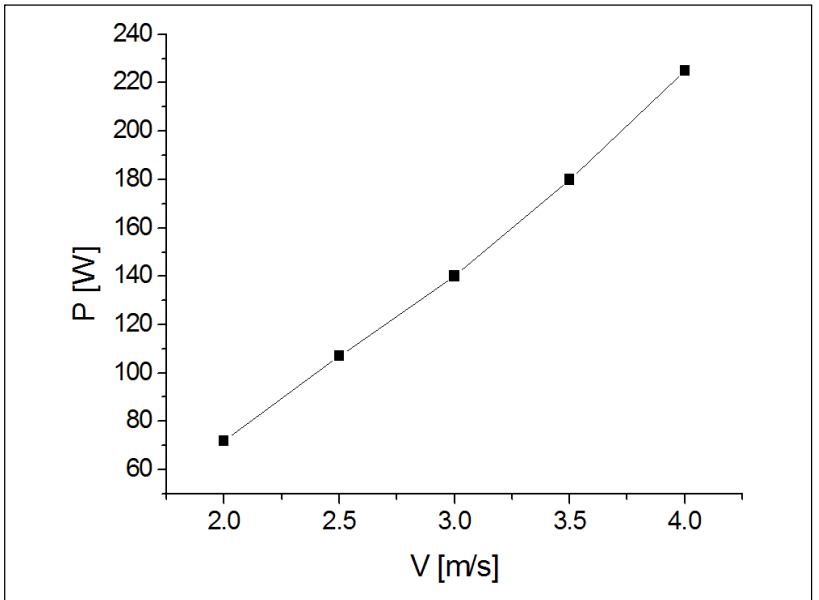

Fig. 8 Output Power v.s. Stream Velocity

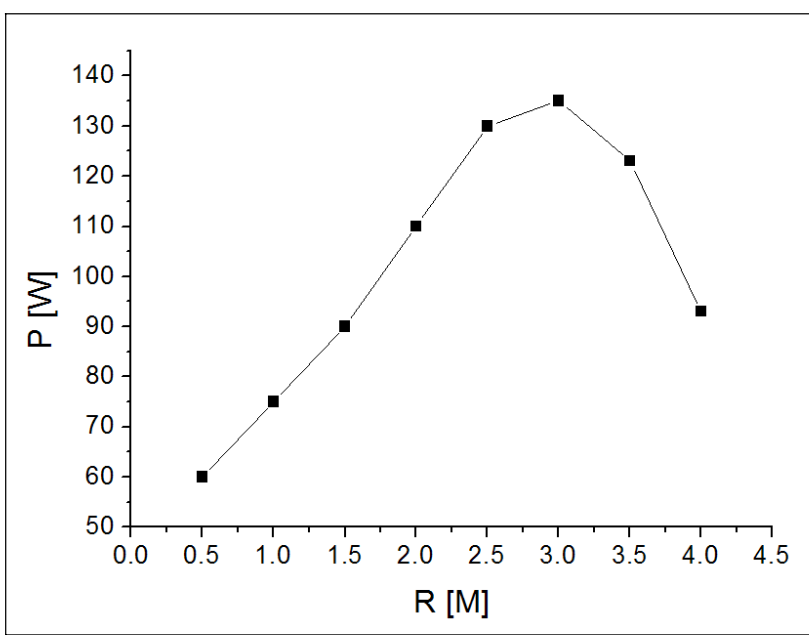

Fig. 9 Output Power v.s. Blade Radius 


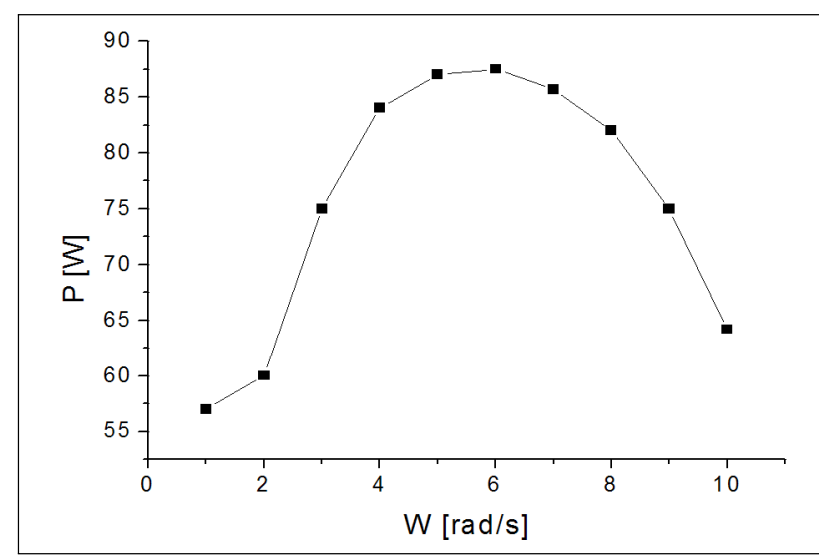

Fig. 10 Output Power v.s. Angular Velocity

증가하게 된다. 하지만 주속비가 일정 값보다 커지면 최대출 력계수인 $\mathrm{Cp}$ 값이 줄어들게 되므로 블레이드의 길이가 $3 \mathrm{~m}$ 일 때 출력 값이 가장 크게 나타나고 이보다 더 크게 증가시켰을 때 출력이 감소하게 된다.

유속을 $2 \mathrm{~m} / \mathrm{s}$, 블레이드의 반지름을 $5 \mathrm{~m}$ 로 고정하고 각속 도를 증가시켰을 때의 결과 값은 Fig. 10과 같다. 식 (4)를 통해 $\lambda$ 는 각속도에 비례하기 때문에 각속도 값을 증가시키게 되면 $\lambda$ 도 커지고 $\mathrm{Cp}$ 값도 증가하게 된다. $\mathrm{Cp}$ 값이 커지면 출 력도 증가하게 된다. 하지만 앞에서 설명한 것과 같이 $\lambda$ 가 일정 값보다 커지면 $\mathrm{Cp}$ 값이 줄어들게 되므로 유속이 일정할 때 최적의 각속도 값이 존재하게 된다는 것을 알 수 있다.

\section{4. 결 론}

본 논문에서는 조류발전 시스템의 특성을 파악하기 위해서 모의실험 장치인 회류수조를 설치하였다. 회류 수조의 로터 는 유속이 $0.9 \sim 1.0 \mathrm{~m} / \mathrm{s}$ 에서 회전하기 시작했으며 회전 이후 로는 관성력에 의해 $0.5 \mathrm{~m} / \mathrm{s}$ 유속까지 회전이 가능했다. 또한 조류발전 시스템 모의실험 장치인 회류수조의 결과 값을 검
증하기 위해서 MATLAB/Simulink를 이용하여 조류발전 시 스템을 모델링하여 시뮬레이션을 수행한 결과 값이 회류수조 에서 측정된 값과 유사한 출력 값이 나오는 것을 확인하였다. 그리고 블레이드의 길이와 각속도의 변화에 따른 출력 값을 측정하였고 이를 통해 일정 유속에서의 블레이드 길이와 각 속도 값을 확인할 수 있었다. 추후 MPPT제어를 조류발전 시 스템에 적용하여 실험을 진행할 것이다.

\section{후 기}

본 논문은 국토해양부의 "해양에너지 전문인력 양성사업" 과 인하대학교의 지원으로 수행된 연구결과입니다.

\section{References}

[1] 박정우, 이기욱, 김동욱, 염기대, 이광수, 박진순, 2005, "조류 발전용 1.2MW 권선형유도발전기 제어를 위한 전력변환장치 개발”, 신재생에너지학회 춘계학술대회 논문집, pp. 520-523.

[2] 조철희, 2007, “조류발전 특성과 국내외 기술개발 동행”, 한국 태양에너지학회, Vol. 6, No. 1, pp. 9-16.

[3] 정해선, 이준민, 나재두, 김영석, 2009, "100KW급 고효율 부 유식 조류발전 시스템의 MPPT 제어”, 대한전기학회 추계학술 대회 논문집, pp. 196-199.

[4] 이두영, 윤동진, 정종규, 양승철, 한병문, 송승호, 2008, "영구 자석동기발전기 풍력시스템의 하드웨어 시뮬레이터 개발”, 전 기학회 논문집, Vol. 56, pp. 951-958.

[5] Janardan Gupta, Ashwani Kumar, 2012, "Fixed Pitch Wind Turbine-Based Permanent Magnet Synchronous Machine Model for Wind Energy Conversion System", Journal of Engineering and Technology, Vol. 2, pp. $52-62$. 


\section{안 원 영}

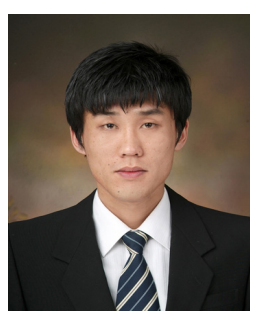

2010년 인하대학교 전기공학과 공학사 2013년 인하대학교 전기공학과 공학석사

현재 인하대학교 해양에너지환경 융합기술연구소 연구원

(E-mail：shuran1004@naver.com)

\section{김 근 수}

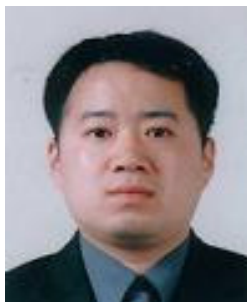

2000년 인하대학교 전기공학과 공학사 2002년 인하대학교 전기공학과 공학석사 2009년 인하대학교 전기공학과 공학박사

현재 영진전문대학 전자정보통신계열 교수

(E-mail : kgs13152@hotmail.com )

\section{조 철 희}

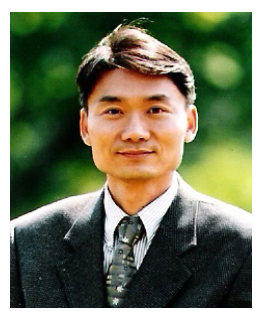

1984년 인하대학교 조선공학과 공학사

1985년 미국 Steven Institute of Technology 해양공학과 공학석사

1991년 미국 Texas A\&M University 해양공학과 공학박사

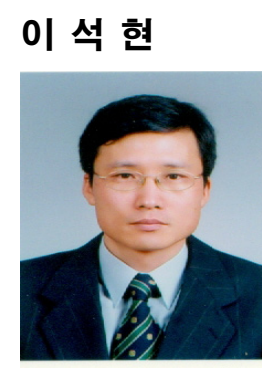

1985년 서울대학교 전기공학과 공학사

1987년 서울대학교 전기공학과 공학석사

1993년 서울대학교 대학원 전기공학과 공학박사

현재 인하대학교 전기공학부 교수

(E-mail : plasma@inha.ac.kr)

\section{이 강 희}

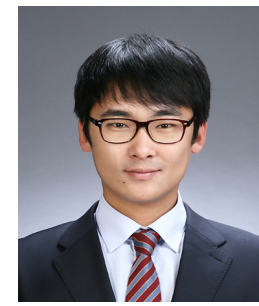

2009년 인하대학교 선박해양공학과 공학사 2011년 인하대학교 조선해양공학과 공학석사

현재 인하대학교 조선해양공학과 박사과정

(E-mail : kanghee@inha.edu)

현재 인하대학교 조선해양공학과 교수

(E-mail : chjo@inha.ac.kr) 